\title{
Characteristics of stable nitrogen isotopes in particulate organic matter and periphyton of a subtropical Chinese watercourse, the Dashahe River
}

\author{
J. Ning ${ }^{(1)}$, H. Zhang ${ }^{(1)}$, X. Li ${ }^{(1)}$, P. Zhong ${ }^{(1)}$, Y. Tang ${ }^{(1)}$, Z. Liu(1),(2), * \\ Received March 13, 2013 \\ Revised June 27, 2013
}

Accepted July 1, 2013

\section{ABSTRACT}

Key-words:

particulate

organic matter,

periphyton,

nitrogen stable

isotope,

subtropical river
The stable nitrogen isotope ratios $\left(\delta^{15} \mathrm{~N}\right)$ of particulate organic matter (POM) and periphyton were measured at sites along the Dashahe River, a short subtropical watercourse in SE China. $\delta^{15} \mathrm{~N}$ values of both POM and periphyton tended to increase from upstream to downstream, ranging from $1.1 \%$ o to $7.4 \%$ o for periphyton and $1.6 \%$ o to $7.2 \%$ o for POM. The $\delta^{15} \mathrm{~N}$ values in both POM and periphyton were depleted at upstream sites with lower concentrations of total nitrogen (TN) and total phosphorus (TP) but enriched at downstream sites with relatively high TN and TP. In addition, $\delta^{15} \mathrm{~N}$ values for POM and periphyton showed a significant negative correlation with distance to the most polluted section of the river, implicating human impact in the pattern of increasing $\delta^{15} \mathrm{~N}$. This study confirms $\delta^{15} \mathrm{~N}$ in POM and periphyton as an excellent indicator of anthropogenic nitrogen pollution in rivers.

\section{RÉSUMÉ}

Caractéristiques des isotopes stables de l'azote dans la matière organique particulaire et le périphyton d'un cours d'eau chinois subtropical, la rivière Dashahe

Mots-clés : matière organique particulaire, périphyton, isotope stable de l'azote, rivière subtropicale
Les rapports des isotopes stables de l'azote $\left(\delta^{15} N\right)$ de la matière organique particulaire (POM) et du périphyton ont été mesurés sur des sites le long du fleuve Dashahe, un cours d'eau subtropical dans le sud de la Chine. Les valeurs $\delta^{15} \mathrm{~N}$ de la $\mathrm{POM}$ et du périphyton ont tendance à augmenter de l'amont vers l'aval, allant de $1,1 \%$ à 7,4 \% pour le périphyton et de $1,6 \%$ à $7,2 \%$ o pour la POM. Les valeurs de $\delta^{15} \mathrm{~N}$ dans la POM et le périphyton sont basses dans les sites amont avec de plus faibles concentrations d'azote total (TN) et le phosphore total (TP) mais plus élevées dans les sites aval avec des concentrations TN et TP relativement plus élevées. En outre, les valeurs $\delta^{15} \mathrm{~N}$ pour la POM et le périphyton ont montré une corrélation négative significative avec la distance à la section la plus polluée du fleuve, impliquant l'impact humain dans le schéma d'augmentation $\delta^{15} \mathrm{~N}$. Cette étude confirme le $\delta^{15} \mathrm{~N}$ de la POM et du périphyton comme un excellent indicateur de la pollution par l'azote d'origine anthropique dans les rivières.

Stable nitrogen isotope ratios $\left(\delta^{15} \mathrm{~N}\right)$ can be used to identify sources and sinks of nitrogen compounds in waterways and to track major biogeochemical processes in aquatic ecosystems (Vander Zanden et al., 2005; Finlay and Kendall, 2007). Several studies have recognized

(1) Department of Ecology and Institute of Hydrobiology, Jinan University, Guangzhou 510632, P.R. China

(2) State Key Laboratory of Lake Science and Environment, Nanjing Institute of Geography \& Limnology, Chinese Academy of Sciences, Nanjing 210008, P.R. China

* Corresponding author: zliu@niglas.ac.cn 


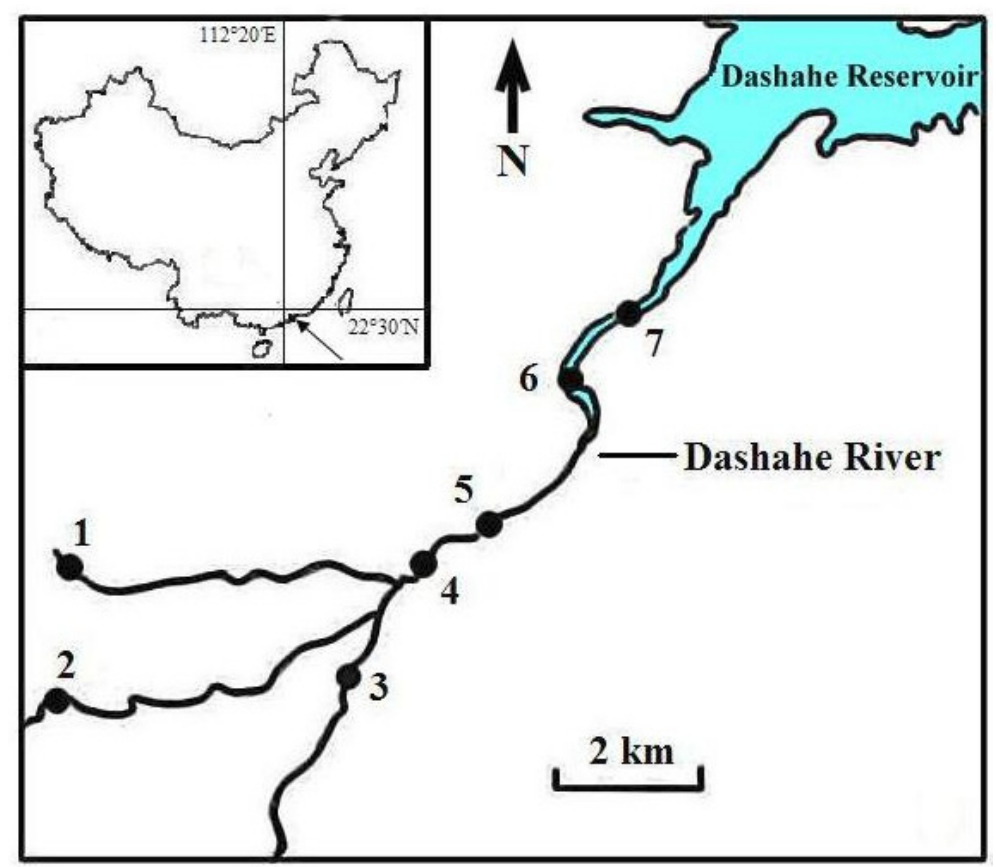

Figure 1

Sampling sites in Dashahe River.

the potential of $\delta^{15} \mathrm{~N}$ for tracing sources of anthropogenic nitrogen in polluted watersheds (Lake et al., 2001; Anderson and Cabana, 2005, 2006). Anthropogenically derived dissolved inorganic nitrogen (DIN) in aquatic ecosystems tends to exhibit distinctive isotopic values, thereby providing a means to identify the pollution sources. For instance, synthetic fertilizers based on ammonia generated from air nitrogen have $\delta^{15} \mathrm{~N}$ values close to $0 \%$, whereas animal manure and wastewater typically possess higher signature values of $\delta^{15} \mathrm{~N}$ (Heaton, 1986; Kendall, 1998). In addition, biogeochemical transformation (denitrification, ammonia volatilization) of nitrogen sources before they enter rivers and further in-stream transformation processes can result in substantial isotopic fractionation (Anderson and Cabana, 2006). Ultimately, DIN (nitrate, ammonia) is assimilated by aquatic plants, whose $\delta^{15} \mathrm{~N}$ profiles may be usefully indicative of anthropogenic nitrogen sources in the watershed. For example, Cole et al. (2005) found that the $\delta^{15} \mathrm{~N}$ values of macrophytes in estuaries and freshwater ponds reliably indicate the presence of wastewater-derived nitrogen into these aquatic ecosystems. Toda et al. (2002) showed that the $\delta^{15} \mathrm{~N}$ values in periphyton can be an excellent indicator of nitrogen sources in a river system.

A distinct longitudinal pattern has been observed in the nutrient levels of water in the Dashahe River, a subtropical river in Kaiping, Guangdong, SE China. This study we investigates the characteristic $\delta^{15} \mathrm{~N}$ signatures of particular organic matter (POM) and periphyton along the river and discusses the implications for tracing the provenance of nitrogen pollution.

Dashahe River is about $50 \mathrm{~km}$ long with a watershed of $470 \mathrm{~km}^{2}$. Seven sites along its length were chosen for sample collection for this study. The distances from lowermost site (site 7) to the upstream sites 1 to 6 are $10.18 \mathrm{~km}, 11.56 \mathrm{~km}, 7.41 \mathrm{~km}, 5.47 \mathrm{~km}, 4.47 \mathrm{~km}$ and $1.29 \mathrm{~km}$ respectively (Figure 1). Human populations and anthropogenic impacts such as those associated with the rearing of livestock (chicken, pigs and geese) increase from upstream to downstream (Nielsen et al., 2013).

Samples were collected in early April 2011. Bulk water samples were collected at each site using a 5-L Tygon water sampler and stored in acid-cleaned polyethylene bottles for transportation to the laboratory. In the laboratory, total phosphorus (TP), total nitrogen (TN), nitrate $\left(\mathrm{NO}_{3}\right.$ $\mathrm{N})$ and ammonia $\left(\mathrm{NH}_{4}-\mathrm{N}\right)$ were measured according to the Chinese standard methods (Jin and Tu, 1990). POM samples were obtained by filtering 2 to $5 \mathrm{~L}$ water through precombusted 
Table I

Total nitrogen $(T N)$, nitrate $\left(\mathrm{NO}_{3}-\mathrm{N}\right)$, ammonia $\left(\mathrm{NH}_{4}-\mathrm{N}\right)$ and total phosphorus (TP) concentrations in Dashahe River.

\begin{tabular}{|l|c|c|c|c|c|c|c|}
\hline \multirow{2}{*}{ Variable } & \multicolumn{7}{|c|}{ Sites } \\
\cline { 2 - 8 } & 1 & 2 & 3 & 4 & 5 & 6 & 7 \\
\hline $\mathbf{T N}\left(\mathbf{m g} \cdot \mathbf{L}^{-1}\right)$ & 0.960 & 0.834 & 0.512 & 0.648 & 1.077 & 1.721 & 1.799 \\
\hline $\mathbf{N O}_{3}-\mathbf{N}\left(\mathbf{m g} \cdot \mathbf{L}^{-1}\right)$ & 0.508 & 0.486 & 0.341 & 0.521 & 0.311 & 0.268 & 0.294 \\
\hline $\mathbf{N H}_{\mathbf{4}} \mathbf{-} \mathbf{N}\left(\mathbf{m g} \cdot \mathbf{L}^{-1}\right)$ & 0.093 & 0.061 & 0.076 & 0.065 & 0.181 & 0.125 & 0.184 \\
\hline $\mathbf{T P}\left(\mathbf{m g} \cdot \mathbf{L}^{-1}\right)$ & 0.014 & 0.010 & 0.047 & 0.009 & 0.074 & 0.077 & 0.036 \\
\hline
\end{tabular}

$\left(500{ }^{\circ} \mathrm{C}, 4 \mathrm{~h}\right.$ ) and preweighted Whatman (GF-F) glass-fiber filters (pore size $\left.0.7 \mu \mathrm{m}\right)$. Filters were then dried to a constant weight at $60^{\circ} \mathrm{C}$. Periphyton was collected from rocks using a wire or nylon brush in a plastic container filled with clean water. All visible non-periphyton particles were removed manually and samples were then filtered through a $100 \mu \mathrm{m}$ mesh, followed by filtration onto precombusted glass-fibre filters and drying at $60{ }^{\circ} \mathrm{C}$. Microscopic examination of periphyton samples collected in this manner showed that most matter comprised an assemblage of diatoms (Gomphonema spp., Navicula spp. and Achnanthes spp.). POM and periphyton samples were analyzed for $\delta^{15} \mathrm{~N}$ on an EA 1112 elemental analyzer coupled to a Hydra 20-20 isotope ratio mass spectrometer. Stable isotope ratios are expressed in the delta $(\delta)$ notation, defined as parts per thousand (per mil, \%o ) deviation from a certified standard:

$$
\delta^{15} \mathrm{~N}(\%)=\left[\left(R_{\text {sample }} / R_{\text {standard }}\right)-1\right] \times 1000
$$

where $R$ is the ratio ${ }^{15} \mathrm{~N} /{ }^{14} \mathrm{~N}$ and the standard is atmospheric $\mathrm{N}_{2}$.

All statistical analyses were performed using SPSS for Windows 16.0 (SPSS INC). Relationships between the distance from lowermost site (site 7) to the other sites and $\delta^{15} \mathrm{~N}$ values of periphyton and $\delta^{15} \mathrm{~N}_{\mathrm{POM}}$ values were assessed using Spearman correlation coefficients.

TN concentrations at the upstream sites $1-4$ were low, ranging from 0.512 to $0.960 \mathrm{mg} \cdot \mathrm{L}^{-1}$, but increased dramatically downstream from site 5 to site 7 . The concentration of $\mathrm{NO}_{3}-\mathrm{N}$ also varied between sites but with an inverse gradient, being higher at sites 1-4 and lower at sites 5-7. Similar to $\mathrm{TN}, \mathrm{NH}_{4}-\mathrm{N}$ levels were low at sites 1-4 but increased dramatically downstream. TP concentrations ranged from 0.009 to $0.077 \mathrm{mg} \cdot \mathrm{L}^{-1}$, with the lowest values recorded at site 4 and highest at site 6 (Table I).

The $\delta^{15} \mathrm{~N}$ values of POM ( $\left({ }^{15} \mathrm{~N}_{\mathrm{POM}}\right)$ ranged from $1.6 \%$ to $7.2 \%$ ond increased from upstream sampling sites to those downriver (Figure 2). The $\delta^{15} \mathrm{~N}$ values of periphyton $\left(\delta^{15} \mathrm{~N}_{\text {periphyton }}\right.$ ) showed a similar pattern, ranging from $1.1 \%$ o to $7.4 \%$. Values for $\delta^{15} N_{\text {POM }}$ were consistently


tend to increase from upstream reaches to the downstream sections of the river. Statistical analyses indicate a significant negative correlation between distance from the polluted downstream site 7 to the other sites and $\delta^{15} \mathrm{~N}$ values of periphyton $\left(R^{2}=0.85, P<0.01, n=7\right)$ and POM $\left(R^{2}=0.74, P<0.05, n=7\right)$.

The $\delta^{15} \mathrm{~N}$ values of POM and periphyton in the Dashahe River increase from upstream to downstream. There are many potential causes of this longitudinal $\delta^{15} \mathrm{~N}$ gradient, including anthropogenic contamination, redox chemistry (e.g. denitrification, ammonium vs. nitrate as the dominant DIN form), and site-specific natural labeling of DIN pools (Finlay and Kendall, 2007). We also note that $\delta^{15} \mathrm{~N}$ values of POM and periphyton were depleted at upstream sites with lower concentrations of TN and TP and elevated at downstream sites with higher total nutrient levels. In addition, $\delta^{15} \mathrm{~N}$ values in POM and periphyton showed significant negative correlations with distance to the most polluted site (site 7).

Biotic $\delta^{15} \mathrm{~N}$ has been proposed as an indicator of anthropogenic nitrogen input in rivers. POM and periphyton are widely distributed in Dashahe River and assimilate nutrients directly from the water, so have excellent potential as indicators. Two primary sources of anthropogenic nitrogen exist in the agricultural watersheds of Dashahe River: synthetic fertilizers applied to fields, and waste from livestock farming. Effluents from these sources are routinely discharged 


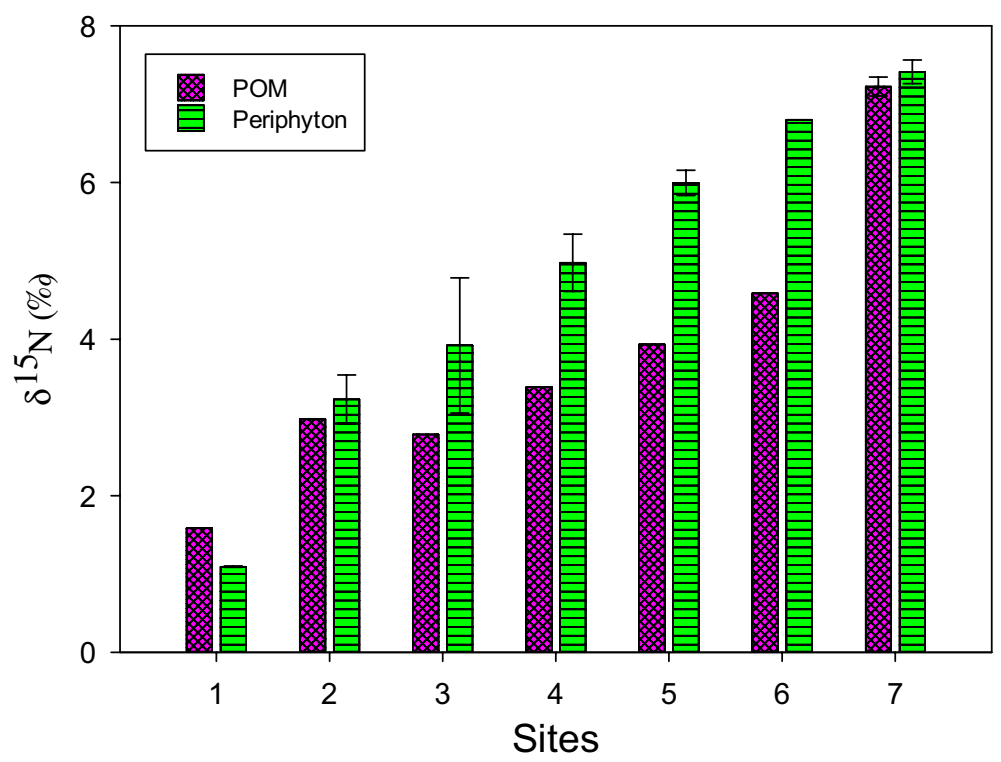

Figure 2

$\delta^{15} \mathrm{~N}$ of particulate organic matter (POM) and periphyton in Dashahe River. Vertical bars indicate standard deviations.

directly into river without any treatment. Different anthropogenic nitrogen sources often have different initial $\delta^{15} \mathrm{~N}$ values. For example, nitrogen originating from fresh animal waste tends to show a slightly higher initial $\delta^{15} \mathrm{~N}$ value than synthetic fertilizers (+5\%。 and $\sim 0 \%$ respectively). So increases in $\delta^{15} \mathrm{~N}$ values of POM and periphyton in downstream sites may be attributable to nitrogen pollution from animals (chicken, pigs and geese). Toda et al. (2002) also reported a significant positive relationship between the $\delta^{15} \mathrm{~N}$ values of periphyton and the percentage contribution to nitrogen loading from sewage and livestock waste. The increase in the $\delta^{15} \mathrm{~N}$ values of periphyton might therefore reflect an accumulation of sewage and livestock waste down the river.

However, initial $\delta^{15} \mathrm{~N}$ values characteristic of synthetic fertilizers $(\sim 0 \%)$ and fresh animal wastes (+5\%) are not high enough to explain all of the variation observed in our study $\left(\delta^{15} \mathrm{~N}\right.$ values of $+1.1 \%$ o to $+7.4 \%$ o for periphyton and $+1.6 \%$ o to $+7.2 \%$ o for POM respectively). Additional enrichment is likely to be due to biogeochemical nitrogen transformations, such as denitrification, which occur both during transport to the river and in-stream. It is reported that denitrification is one of the primary drivers of further elevations in $\delta^{15} \mathrm{~N}$ values (Heaton, 1986; Kendall, 1998). Some studies have shown that the high $\delta^{15} \mathrm{~N}$ values of aquatic ecosystems in agricultural settings could be primarily an indicator of nitrogen loss through denitrification (Anderson and Cabana, 2005; Vander Zanden and Diebel, 2009). Vander Zanden and Diebel (2009) suggested that sites with high $\delta^{15} \mathrm{~N}$ values had low nitrate concentrations, a pattern that was consistent with nitrogen loss by denitrification. This is supported by our results, which show low values for ammonia at upstream sites increasing dramatically downstream, while nitrate levels show the inverse pattern. Further elevated $\delta^{15} \mathrm{~N}$ values in periphyton and POM at downstream sites of Dashahe River can probably be attributed to denitrification.

The $\delta^{15} \mathrm{~N}$ values of POM and periphyton we observed reflect anthropogenic nitrogen pollution in Dashahe River. However, the results are based on a single sampling event. The possibility of seasonal trends in $\delta^{15} \mathrm{~N}$ values is a good incentive for future studies, especially given that the use of synthetic fertilizer in this region and the hydrological conditions of the river both show clear seasonal patterns, which might be expected to affect $\delta^{15} \mathrm{~N}$ values of POM and periphyton. 


\section{ACKNOWLEDGEMENTS}

The authors thank Binghui Chen, Xiao Yu, Shen Xu, Kun Hu, Min Zhou and Weimin Rao for field and laboratory support, and Amy-Jane Beer for the English improvements of this manuscript. This study was supported by National Foundation of Science of China (No. U1033602 and U0733007) and the National Basic Research Program of China (No. 2012CB956100).

\section{REFERENCES}

Anderson C. and Cabana G., 2005. $\delta^{15} \mathrm{~N}$ in riverine food webs: effects of $\mathrm{N}$ inputs from agricultural watersheds. Can. J. Fish. Aquat. Sci., 62, 333-340.

Anderson C. and Cabana G., 2006. Does $\delta^{15} \mathrm{~N}$ in river food webs reflect the intensity and origin of $\mathrm{N}$ loads from the watershed? Sci. Total Environ., 367, 968-978.

Cole M.L., Kroeger K.D., McClelland J.W. and Valiela I., 2005. Macrophytes as indicators of land-derived wastewater: Application of a $\delta^{15} \mathrm{~N}$ method in aquatic systems. Water Resour. Res., 41, W01014.

Finlay J.C. and Kendall C., 2007. Stable isotope tracing of temporal and spatial variability in organic matter sources to freshwater ecosystems. In: Michener R.H. and Lajtha K. (eds.), Stable Isotopes in Ecology and Environmental Science, Blackwell Publishing, 283-333.

Heaton T.H.E., 1986. Isotopic studies of nitrogen pollution in the hydrosphere and atmosphere: a review. Chem. Geol., 59, 87-102.

Jin X.C. and Tu Q.Y., 1990. The standard methods for observation and analysis in Lake eutrophication, 2nd edn., China Environmental Science Press, Beijing (in Chinese).

Kendall C., 1998. Tracing nitrogen sources and cycling in catchments. In: Kendall C. and McDonnell J.J. (ed.), Isotope tracers in catchment hydrology, Elsevier, Amsterdam, 519-576.

Lake J.L., McKinney R.A., Osterman F.A., Pruell R.J., Kiddon J., Ryba S.A. and Libby A.D., 2001. Stable nitrogen isotopes as indicators of anthropogenic activities in small freshwater systems. Can. J. Fish. Aquat. Sci., 58, 870-878.

Nielsen A., Trolle D., Me W., Luo L., Han B.P., Liu Z, Olesen J.E. and Jeppesen E., 2013. Assessing ways to combat eutrophication in a Chinese drinking water reservoir using SWAT. Mar. Freshwater Res. $64,475-492$

Toda H, Uemura Y., Okino T., Kawanishi T. and Kawashima H., 2002. Use of nitrogen stable isotope ratio of periphyton for monitoring nitrogen sources in a river system. Water Sci. Technol., 46, 431-435.

Vander Zanden M.J. and Diebel M.W., 2009. Nitrogen stable isotopes in streams: effects of agricultural sources and transformations. Ecol. Appl., 19, 1127-1134.

Vander Zanden M.J., Vadeboncoeur Y., Diebel M.W. and Jeppesen E., 2005. Primary consumer stable nitrogen isotopes as indicators of nutrient source. Environ. Sci. Technol., 39, 7509-7515. 